\title{
Towards digital energy (experience of digital technology implementation by Russian companies)
}

\author{
Yulia Zhilkina, ${ }^{1, *}$, Dmitry Vodennikov ${ }^{2}$ \\ ${ }^{1}$ Candidate of economic sciences, Assets management Department, Federal Grid Company of Unified Energy System, Moscow, Russia \\ ${ }^{2}$ Chairman of the board - Chief Engineer, Federal Grid Company of Unified Energy System, Moscow, Russia
}

\begin{abstract}
Today, digitalization is increasingly "capturing" the world economy. The inclusion of Russia in this trend is a matter of domestic companies maintaining their positions in the international arena. In the future, the creation of our own high-tech solutions will allow our country not only to win a competitive race in traditional markets, but also to reach new borders and take a leading position in the global market of complex systems and services of intellectual energy.
\end{abstract}

\section{Introduction}

Today, digitalization is increasingly "capturing" the world economy. The inclusion of Russia in this trend is a matter of domestic companies maintaining their positions in the international arena. In the future, the creation of our own high-tech solutions will allow our country not only to win a competitive race in traditional markets, but also to reach new borders and take a leading position in the global market the complex systems and intellectual energy services.

Innovative development is a driver of increasing efficiency in the electric power industry, as well as reliability, quality and economy energy supply to consumers on the basis modern technologies with transformation of them into the intelligent core of technological infrastructure the electric power industry.

The priority direction of innovative development of PJSC FGC UES is the introduction digital technologies and platforms. In modern conditions, the use digital data is a key factor of production in all spheres the economy, a condition of competitiveness and economic development of the country, ensuring the growth of the quality of life of people. The transition to digital mode of operation is a response to external technological challenges and future structural changes in the energy system.

\section{Major trends of energy complex development}

Within framework concepts of clean (green, low-carbon) sustainable development Global energy transformation through introduction new technologies (including digital technologies) is taking place. Major trends in the energy sector include:

- Creation of new and modernization of existing transport infrastructure (gas pipelines, oil pipelines, high-capacity product pipelines, laid including in hardto-reach and remote regions, sea and land terminals for fuel transhipment, new generation networks, other facilities);

- Modernization of the thermal generation segment (increase of efficiency of boilers and turbines of gas and coal-fired power plants/CHPP, reduction of fuel consumption, co-generation, switching of coal-fired power plants to gas and biomass, change of quality composition of used gas by inclusion of hydrogen, other substances contributing to reduction of harmful emissions into the environment, increase of heating value of energy carrier and other methods);

- Expansion of RE-capacity in electric and thermal power (using water, wind, solar, Earth heat, biomass, household and industrial waste);

- Modernization of the nuclear industry through the introduction of technologies that reduce production and operational risks and create small-capacity power units (except for individual countries that do not develop this direction for social, economic and other reasons);

- Introduction of energy-efficient and resource-saving technologies in all sectors of the energy sector;

- Construction of air, cable and combined long-distance and super-long-distance transmission lines with alternating and direct current;

- Introduction of technologies to capture and absorb carbon dioxide, sulphur and other harmful substances, creation of carbon dioxide storage facilities;

- Creation of active and adaptive networks ("smart") the distributive systems uniting [1] industrial facilities of generation of various power and type (by the form the energy carrier and the used technologies of transformation of a substance/resource to energy), [2] the centralized energy stores, [3] electric transport, [4] household power stations, electric systems;

- Partial decentralization of energy supply systems.

* Corresponding author: zhilkina.yulia@gmail.com 
Developed States control the situation in world energy direct the development of economic and other ways: through public opinion formation, standards development, indicators systems, recommendations to politicians, i.e. "push" society to make concrete decisions. In 2018, International Economic Forum using the Energy Transition Index (see table 1) presented for the first time rating of 114 States ranked, which on several dozen indicators, assesses the level of readiness of national energy to integrate into a future safe, sustainable, affordable and universal energy system, which creation is also a global challenge.

Table 1. Energy Transition Index-2018 index of the certain countries of the world

\begin{tabular}{|c|c|c|}
\hline Rating & Country & Index \\
\hline 1 & Sweden & 75,8 \\
\hline 2 & Norway & 75,0 \\
\hline 3 & Switzerland & 72,9 \\
\hline 4 & Finland & 72,4 \\
\hline 5 & Denmark & 72,4 \\
\hline 54 & Armenia & 55,3 \\
\hline $\mathbf{7 0}$ & Russia & $\mathbf{5 0 , 9}$ \\
\hline 75 & Kazakhstan & 49,7 \\
\hline 112 & Kyrgyzstan & 39,3 \\
\hline
\end{tabular}

\subsection{New technologies and energy.}

Digital introduction (as well as space and biotechnology) into the energy sector began more than half a century ago and continues to be carried out as a matter of priority, following the industries of the militaryindustrial complex, steadily, at all technological stages and "floors" (During field exploration, production, transportation, storage, processing, energy distribution, waste management, energy trade). In order to optimize production, increase reliability and availability of safety of power supply (see Table 2).

Natural-like technologies, as "core" of the next technological order, make it possible to improve the efficiency solving multifaceted problems of sustainable "clean" development, including: (1) resource consumption optimization , (2) anthropogenic influence on the environment reduction, (3) efficiency increase of fuel and energy industries, (4) predictability increase demand and supply for energy, (5) consumers and producers market coverage expansion, "energy" poverty reduction, (6) living standards of the population increase, and even (7) the cost reduction of unit energy.

Digital technologies are transforming not only the sphere of production, but also the sector of transportation/distribution of electricity, the development of which is going towards the creation of active-adaptive ("smart") electricity networks aimed at solving the key problems sustainable development, including:

- Combine into a common/unified energy system generating objects, which differ in power and type of energy carrier used, physically located at short, long and ultra-long distances;

- Provide continuous monitoring of equipment condition, flows, power accumulation and distribution;
- To expand scope interaction market participants (consumers with suppliers and among themselves in various combinations), to implement principle of "sending excess to the network - obtaining energy in case of shortage."

Table 2. Digital Applications in Global Energy 2018

\begin{tabular}{|c|c|c|}
\hline $\begin{array}{l}\text { Activity } \\
\text { Type }\end{array}$ & Type of work/technology & $\begin{array}{l}\text { Leading } \\
\text { country }\end{array}$ \\
\hline $\begin{array}{l}\text { Geological } \\
\text { exploration }\end{array}$ & $\begin{array}{l}\text { Aerospace survey of the Earth 's } \\
\text { surface, construction of virtual } \\
\text { models of subsoil and mining } \\
\text { schemes (geological- } \\
\text { mathematical modeling) }\end{array}$ & $\begin{array}{l}\text { USA, } \\
\text { Russia }\end{array}$ \\
\hline Drilling wells & $\begin{array}{l}\text { With significant distance from } \\
\text { vertical and high length (about } 15 \\
\mathrm{~km} \text { ), self-propelled, non- } \\
\text { navigational, offshore drilling } \\
\text { platforms }\end{array}$ & $\begin{array}{l}\text { USA, } \\
\text { France, } \\
\text { Russia }\end{array}$ \\
\hline $\begin{array}{l}\text { Production of } \\
\text { liquid and } \\
\text { gaseous } \\
\text { hydrocarbons }\end{array}$ & $\begin{array}{l}\text { Hydraulic fracturing, production } \\
\text { technologies in Arctic, offshore } \\
\text { and deep oceans, underwater } \\
\text { deserted production complexes }\end{array}$ & $\begin{array}{l}\text { USA, } \\
\text { Canada, } \\
\text { Norway, } \\
\text { France, } \\
\text { Russia, } \\
\text { China }\end{array}$ \\
\hline $\begin{array}{l}\text { Preparation } \\
\text { for and } \\
\text { transportation } \\
\text { of oil and gas }\end{array}$ & $\begin{array}{l}\text { Cleaning, conversion to different } \\
\text { phases, transhipment and } \\
\text { transportation by land and sea }\end{array}$ & $\begin{array}{l}\text { Russia, } \\
\text { USA, } \\
\text { Canada, } \\
\text { Qatar, } \\
\text { Australia, } \\
\text { China }\end{array}$ \\
\hline $\begin{array}{l}\text { Oil and gas } \\
\text { refining }\end{array}$ & $\begin{array}{l}\text { Release nano - and biopolymers, } \\
\text { biotechnological, anticorrosive, } \\
\text { crystal, fire-resistant materials, } \\
\text { materials for transformation of } \\
\text { energy, biosensors, } \\
\text { pharmaceutical products }\end{array}$ & $\begin{array}{l}\text { USA, } \\
\text { Japan, } \\
\text { Germany, } \\
\text { Great } \\
\text { Britain, } \\
\text { France, } \\
\text { China, } \\
\text { India, } \\
\text { Brazil, } \\
\text { Russia }\end{array}$ \\
\hline $\begin{array}{l}\text { Coal } \\
\text { production } \\
\text { and } \\
\text { processing }\end{array}$ & $\begin{array}{l}\text { Gasification, flexible robotic } \\
\text { systems based on artificial } \\
\text { intelligence, deserted production, } \\
\text { unmanned transport (mines, cuts, } \\
\text { etc.), nano- and biotechnology of } \\
\text { coal and waste processing }\end{array}$ & $\begin{array}{l}\text { United } \\
\text { Kingdom, } \\
\text { Japan, } \\
\text { United } \\
\text { States, } \\
\text { Germany, } \\
\text { Czech } \\
\text { Republic, } \\
\text { Russia, } \\
\text { South } \\
\text { Africa }\end{array}$ \\
\hline $\begin{array}{l}\text { Atomic } \\
\text { sector }\end{array}$ & $\begin{array}{l}\text { Computer design and product } \\
\text { lifecycle management, security } \\
\text { systems, flexible robotic systems } \\
\text { based on artificial intelligence, } \\
\text { deserted production }\end{array}$ & $\begin{array}{l}\text { Russia, } \\
\text { USA, } \\
\text { France, } \\
\text { Great } \\
\text { Britain, } \\
\text { Germany }\end{array}$ \\
\hline $\begin{array}{l}\text { Power } \\
\text { industry }\end{array}$ & $\begin{array}{l}\text { Active adaptive networks, DC } \\
\text { power transmission, } \\
\text { superconducting-based AC } \\
\text { transmission }\end{array}$ & $\begin{array}{l}\text { USA, } \\
\text { European } \\
\text { Union, } \\
\text { Republic } \\
\text { of Korea, } \\
\text { China, } \\
\text { India, } \\
\text { Russia }\end{array}$ \\
\hline Production of & On land, in the oceans and seas & China, \\
\hline
\end{tabular}




\begin{tabular}{|l|l|l|}
\hline gas hydrates & & $\begin{array}{l}\text { Japan, } \\
\text { USA, } \\
\text { Canada }\end{array}$ \\
\hline $\begin{array}{l}\text { Renewable } \\
\text { energy }\end{array}$ & $\begin{array}{l}\text { Solar, geothermal, offshore and } \\
\text { terrestrial wind power, biofuel } \\
\text { technologies }\end{array}$ & $\begin{array}{l}\text { USA, } \\
\text { Brazil, } \\
\text { Germany, } \\
\text { Denmark, } \\
\text { Norway, } \\
\text { Spain, } \\
\end{array}$ \\
& & $\begin{array}{l}\text { Iceland, } \\
\text { Russia, } \\
\text { China, } \\
\text { Japan }\end{array}$ \\
\hline $\begin{array}{l}\text { Activity } \\
\text { Type }\end{array}$ & Type of work/technology & $\begin{array}{l}\text { Leading } \\
\text { country }\end{array}$ \\
\hline $\begin{array}{l}\text { Geological } \\
\text { exploration }\end{array}$ & $\begin{array}{l}\text { Aerospace survey of the Earth 's } \\
\text { surface, construction of virtual } \\
\text { models of subsoil and mining } \\
\text { schemes (geological- } \\
\text { mathematical modeling) }\end{array}$ & $\begin{array}{l}\text { USAsia } \\
\end{array}$ \\
\hline
\end{tabular}

The countries of EU, USA, Japan, China, Republic of Korea, and Australia demonstrate the greatest success in the construction of "intellectual" networks. From a technical point of view, smart networks cannot yet be considered breakthrough solutions, given the fact that their creation and development are based on known principles and technologies.

In other words, in the modern network complex there is a process of deep modernization. More efficient, reliable and safe equipment (often on a new element base) is introduced, while the network structures created continue to serve as "closing" technologies for the current technological order. The policy of comprehensive digitalization is aligned with the global policy of combating climate change, the genesis of which is not defined by science. The main beneficiaries of these processes are large and ultra-large TNCs with high scientific and technological potential, developed production base and trade and sales infrastructure.

\subsection{Interpretation of the concept of "digitalization"}

Digital economy - the system of the economic, social and cultural relations based on use of digital information and communication technologies.

The Digital Energy Development Center insists on its own unique content having in terms of "digital energy" and "digitalization". In digital energy the main concept is "economy." It should be noted that the terms "digital energy" and "digitalization" have emerged in the context of digital economy formation processes, and it makes sense to consider them only in this connection. It follows from the many definitions of the digital economy that economic activity, commercial transactions and professional interactions based on new principles through the use of information and communication technologies are a special subject.

The essence of digital energy is the re-assembly and development of a set of industrial and economic relations in the industry based on digital approaches and means. In sum, in the phrase "digital economy" (and thus "digital energy"), the defining word is "economy," and the adjective "digital" only indicates the means to achieve the goal.

The concept of "digital economy" was best defined in 1995 by computer scientist Nicholas Negroponte [1]. He used the following metaphor to represent the essence of this concept: "Transition from the movement of atoms to the movements of bits" and presented the concepts of weight, raw materials and transport - shortcomings of the past, putting them as opposed to the concept of the absence of the weight of goods, virtually.

According to the European Community (EU), the digital economy is the result of the transformational effects of new general-purpose technologies in the field of information and communication [2]. This has affected all sectors of the economy and social activities, e.g. retail, transport, financial services, manufacturing, education, health care, media, etc.

Digitalization usually also means a wider use of data. Modern substations already provide a huge amount of data, and by purposefully adding new devices and sensors to the substation automation system (ideally designed with an open architecture) the amount of data may still be increased once this seems to be justified by the benefits achieved.

In this context, one highly relevant application area of substation data is asset management support. The acquisition and intelligent analysis of data (including pattern recognition) allows giving early warnings to induce preventive maintenance actions assures the increased availability of important assets like transformers or switchgears and supports the definition of an effective investment and maintenance strategy.

When it came to the use of computing digitization replaced computerization, computers and information technology to address selected economic challenges. [3]

\subsection{Main documents}

President of the Russian Federation Vladimir Putin signed a Decree "On National Goals and Strategic Tasks for the Development of the Russian Federation for the Period up to 2024" May 07, 2018. The Decree sets priorities for the digital transformation of the country's economy, including specifically the energy sectors, in an extremely concentrated manner.

Digital transformation (digitalization) in energy is primarily the creation of new business models, services and markets based on the capabilities of the digital economy Digitalization is not only a fashionable technological process, but also a much needed process! "Figure" in energy should give the same qualitative information leap as the arrival of IT-technologies in due time The advent of computer networks has increased the efficiency of all production processes and brought the world to a new level of communication Energy is one of the last areas not yet digitized It is obvious that such modernization requires considerable costs However, it in turn will have positive effects: it will open up opportunities for new equipment and new approaches that will allow to provide consumers with electricity 
services in a more comfortable mode Intelligent energy will fundamentally change the speed, reliability and cost of work - and this is the saving of both labor and money.

\subsection{Objectives of digital transformation of electric power industry}

The main challenge of digital energy is eliminate dramatically rising costs of integrating distributed energy and market transactions. The goal of digital transformation is to change the logic of processes and move the company to risk-based management based on digital adoption and big data analytics.

Digital Transformation Objectives: (1) Adaptability of the company to new challenges and challenges; (2) Improvement of power supply reliability characteristics of consumers; (3) Improving the efficiency of the company; (4) Improved availability of grid infrastructure; (5) Development of human resources and new competencies; (6) Diversification of the company's business through additional services.

Basic principles of digital transformation are:

Within the company: - ensuring observability of network objects and modes of their operation; technological and corporate processes management automation; - automated risk-oriented management application principles; - construction digital CIM-model according to a single industry standard and information interaction with all counterparties (Networks, consumers and other entities of the electric power industry); integration and integration of various IT systems at hierarchical levels; - integration of network information (technological and corporate) systems;

With regard to regulated activities of the company: ensuring reduction of electricity losses; - optimization of operating and capital expenditures; - reduction of technological connection time; - improvement of reliability of consumers 'electricity supply; - increase of openness and transparency of the company's activities; containment of tariff growth rate;

To the loop of interaction with other entities: creation of a publicly available, reliable, transparent and verifiable system of intelligent commercial accounting of electricity; - creation of infrastructure for simple and effective interaction with consumers (load management, distributed generation, "requests"); - creation opportunity for automation contract relations (smart contracts) in terms of provision of transmission services, technological connection, etc.;

With regard to the development of new unregulated services, the development of a fundamentally new infrastructure for an affordable, efficient and flexible process of electricity exchange among all market stakeholders with minimal transaction costs.

The potential benefits of applying digitalization for substation asset management are numerous: The efficiency of operational maintenance of primary assets and patch management of secondary assets can be significantly improved. Investments into new primary assets can be made at the right point of time, considering their actual heath status and their strategic relevance.
Unplanned downtimes can be avoided, with a positive effect on grid availability and asset productivity. Decisions can be made more consciously and faster.

The digital transformation will increase the energy security of the regions of the country by creating new infrastructure opportunities and ensuring a new standard of living for the population thanks to new standards of service. The systemic effects of digital technologies introduction to be increased reliability of electric power supply and reduction of the duration of power supply interruptions are expected, possibility to optimize energy consumption at the level of end-users, increase efficiency of asset use, reduce power losses, accessibility for renewable distributed energy. Table 3 shows the main effects of the Concept implementation.

Table 3. Key Effects from Concept Implementation

\begin{tabular}{|l|l|}
\hline Subject & \multicolumn{1}{|c|}{ Effects } \\
\hline State & -Ensuring energy independence and \\
infrastructural security of economic \\
development. \\
-Advance modernization of the underlying \\
infrastructure company. \\
-Radical improvement of the quality and \\
accessibility of transmission and \\
technological connection services, \\
development of competitive markets for \\
related services. \\
-Containing tariff growth. \\
\hline Company & - Getting savings in the implementation of \\
investment programs, and, accordingly, the \\
possibility of ahead of the development of \\
network infrastructure while increasing the \\
profitability of the company's business. \\
Ensure that infrastructure is prepared to \\
develop new challenges, improve sour \\
quality and reliability of consumer energy \\
supply. \\
- Increase the speed and quality of decision- \\
making at all levels of the company's \\
management. \\
-Reducing losses by timely detection of \\
uncontracted and unaccounted electricity \\
consumption. \\
Reducing the cost of ongoing equipment \\
maintenance (OPEX) - moving from \\
planned repairs to repairs as of the state. \\
-Optimizing the logistics of equipment \\
delivery. \\
-Improving staff competence.
\end{tabular}




\section{Digital technologies by Russian energy companies: implementation practical}

The resource for increasing the efficiency and quality of FGC's power grid infrastructure is found in the use of digital technologies.

Main priority is the development of a network of low-maintenance digital facilities with a high degree of reliability. In addition, over the past ten years, the Company has been introducing elements of digital substation technology on the basis of the international standard IEC 61850. By 2025, we will build 32 high and ultra-high voltage facilities with integrated digital solutions. At the same time, all substations will be equipped with digital communication systems capable of remote control from unified centers.

However, digitisation is not the only task of innovative development. In 2017, two of FGC's projects received the national status. The first of them is focused on increased energy efficiency of substations, while the second relates to the use of high-temperature superconductors. This technology minimises energy losses during transport and the subject of scientific research in many countries. Last year FGC UES completed testing the world's largest superconducting cable line. It will be put into operation in 2020 in St. Petersburg.

In 2018, in particular, the connections between the power systems of the Northwest and the Centre have been strengthened, previously isolated Yakutia has become part of Russia's Unified Energy System thanks to the 750-kilometre power transit, and the Tobol substation was commissioned - the first ultra-high voltage facility to integrate a set of digital solutions.

\begin{tabular}{|c|c|}
\hline PJSC Rosseti & PJSC "FGC UES" \\
\hline $\begin{array}{c}\text { - Intelligent metering } \\
\text { devices }\end{array}$ & $\begin{array}{c}\text {-Remote control of } \\
\text { substation equipment }\end{array}$ \\
\hline - "Smart Networks" & -Digital substations \\
\hline
\end{tabular}

Currently, when creating digital substations, the Federal Grid Company seeks to solve two tasks: reliability improvement and cost reduction. The former is achieved through a continuous monitoring of the component integrity and operability. The overall facility cost is determined by the expenditures on its design, construction and maintenance. Today, if a digital substation is erected from scratch, it turns out more expensive than a conventional substation. However, if some of the maintenance costs can be avoided, and the substation equipment is inspected only if needed (rather than scheduled), the digital substation will eventually be cheaper.

Instead of an electrician inspecting the secondary circuits, we would be forced to employ a well-paid cyber security expert and a system administrator, who would repeatedly take care of the complex information systems.
Such systems would fail during the operation because the server's operational lifetime is 10 years and the substation is in service for around 40 years. All costs associated with the IT infrastructure modernization would be included in the tariff, so we could face a modern and innovative power industry with huge tariffs for electricity and a minimum number of consumers. The Federal Grid Company is working on the creation of digital substations and considers them quite promising. However, if we fail to justify the costs for cyber security solutions by showing evidence they do improve the reliability of the electrical facility operation, power engineers will once again have to resort to the electromechanical relays manufactured at "Cheboksary Electromechanical Factory" (which have been in service for more than 40 years without any failures).

Key Digitalization Effects:

- Reducing the duration of power outages and the average frequency of technological failures (SAIDI / SAIFI) by $5 \%$ by 2024 ;

- Increasing the level of technical condition of production assets of the electric power industry for facilities by $5 \%$ by 2024 without increasing the cost of maintaining the technical condition;

- A $20 \%$ reduction in accident rate at electric power facilities related to the technical condition of production assets by 2024 .

Digitalization in the energy sector is necessary because it will ensure uninterrupted power supply, preventing accidents in advance. Digital technologies are set to transform grid operations. Increasingly, drones will carry out inspections, replacing workers in the field, while sensors enable real-time network monitoring. Predictive maintenance, based on machine learning and artificial intelligence, will reduce power outages and improve companies' investment and maintenance decisions. And robotic process automation will speed up back-office functions. Sensor, data collection, and storage costs are one-tenth what they were ten years ago, and the resulting proliferation of data and advanced analytics will also boost efficiency. But while digital transformation of the grid is an opportunity, it also adds complexity and involves fundamental changes in operating models.

\section{References}

1. A. Dobrynin, K. Chernykh, V. Kupriyanovsky, P. Kupriyanovsky, S. Sinyagov Digital economy various ways to the effective application of technologies // International Journal of Open Information Technologies ISSN: 2307-8162. vol. 4. (2016)

2. OECD Digital Economy Outlook 2015, OECD July 15, 2015 OECD Publishing [Electronic resource] URL: https://read.oecd-ilibrary.org/science-andtechnology/oecd-digital-economy-outlook2015 9789264232440- en \# page26 appeal date: $07 / 19 / 2019$ 
3. Yu. Zhilkina Electricity development: vertical integration or further liberalization of the industry? // Bulletin of KGEU, No. 2 (38). (2018)

4. P. Livinsky Digitalization of networks will become the basis for future transformation processes in the electric power industry // Website of PJSC Rosseti [Electronic resource]

URL: https://www.rosseti.ru/press/news/index.php?ELEM ENT_ID=34079 (accessed: 07/03/2019).

5. Digital transition to the electric power industry of Russia // Expert-analytical report, ed. Knyaginina V.N., D.V. Kholkina. Moscow: Publishing House of the Center for Strategic Research Foundation Innovation Development Project Centre. (2017) 